\title{
Personality, Attitude and Behavioural Components of Financial Literacy: A Comparative Analysis
}

\author{
Erzsébet Németh ${ }^{1}$, Boglárka Zsótér ${ }^{2}$ \\ ${ }^{1}$ Budapest Metropolitan University, Hungary \\ ${ }^{2}$ Corvinus University of Budapest, Hungary \\ enemeth@metropolitan.hu*, boglarka.zsoter@uni-corvinus.hu
}

\begin{abstract}
Since the financial crisis in 2008 the investigation of financial literacy-especially its components (personality, attitudes, behaviour etc.) - is in the limelight. Modern economics have recognized that in order to effectively forecast financial and economic processes it is primordial to understand the attitudes of the members of society toward finances, as well as the characteristics of various social group sharing the same views and behaviours. In 2015 two relevant pieces of research were conducted in this topic in Hungary. One focuses on the financial personality types, while the other investigates Hungarians' financial culture in general based on the research methodology of the OECD. Based on these two databases our comparative study highlights the main characteristics of financial personality types. The three clusters based on the OECD research cover the nine personality types from the results of the other Hungarian research. Our findings show that the cluster of "anxious unsatisfied" encapsulates the "economizers with little money", the "price sensitive" and the "collector" personality types. Furthermore, the "satisfied conscious" covers the "order creates value", the "diligent" and the "planner" personality types. Finally, the "moderately anxious unconsidered" involves the "ups and downs", the "money-devouring" and the "cannot control finances" personality types. The clusters identified during the research show idiosyncratic financial and psychological vulnerability and/or protection.
\end{abstract}

Keywords: Personality, attitude, behaviour, financial literacy

\section{Introduction}

The need for the development of financial literacy has been continually present in the past decades. However, it came to the centre of attention only in connection with the financial crisis unfolding in 2008 (Botos et al., 2012). The notion of financial literacy has been defined by many and in many ways. Related research in Hungary and abroad has often been initiated and financed by the largest financial services providers. In this context the view that the more familiar the population is with banking products and the more financial risks they are willing to take, the more advanced their financial literacy is has been widely accepted and held to be axiomatic by researchers. According to the most accepted definition in Hungary, "financial literacy is the level of financial knowledge and skills that enables individuals to identify and subsequently interpret basic financial information in order to be able to make conscious and prudent decisions and to be able to assess the potential future financial and other consequences of their decision" (Magyar Nemzeti Bank, 2014). The State Audit Office of Hungary's definition equally emphasizes the appropriate levels of financial knowledge, and the ability to manage money and states that financial literacy is above all about having a realistic self-image of one's own financial literacy and making adjusted decisions (Huzdik, Béres \& Németh, 2014). The present research examines the personality, attitude, and behavioural components of financial literacy. It is based on the premise that financial literacy is not only determined by knowledge and skills but also by factors such as attitudes towards money, behavioural patterns, financial planning, an ability to prolong one's satisfaction of needs, and whether an individual is capable of "keeping their finances in order" (Zsótér et al., 2016).

The main aim of the present study is to compare the results of a study about financial personalities conducted in Hungary in 2015 on behalf of the Financial Compass Foundation (Pénziránytü Alapítvány) with those of a study about financial literacy conducted in 2015 by market research company GfK and the Financial Compass Foundation. A 36-item financial personality test was developed by Erzsébet Németh that was completed, during the summer of 2015, by 3088 individuals (Németh et al., 2016; Béres et al., 2015). The test examines the economic and psychological aspects of individuals' relationship with money. A factor analysis revealed 9 factors that cover financial personality types. A 12 -item scale examining respondents' financial attitudes and behaviour was part of the study of financial literacy based on the OECD questionnaire. 1000 individuals were surveyed, representing the population of Hungary by age, gender and type of settlement. A factor analysis was performed on the financial attitude and behaviour scale, followed by a cluster analysis based on factor 
averages. The thus obtained three factors and three clusters were compared with the results of the financial personality study. Each cluster obtained in the OECD study covers three factors of the financial personality study. A review of the concepts of financial attitude, financial personality, financial decisions, and financial behaviour served as the theoretical foundations of the study.

\section{Literature Review}

Money does not only have intrinsic value but also outstanding features and strong motivating power (Opsahl and Dunnette, 1966). Furthermore it is a highly subjective concept, meaning something different for each person (Wernimont and Fitzpatrick, 1972). For these reasons, in the following, the most prominent research directions and results related to financial personality and financial attitudes are synthesized. The extensive research in the field goes back to the beginning of the 1970s; the following theoretical review gives an overview of the most prominent results since then. Yamauchi and Templer (1982) developed a standard measure of financial attitude called the Money Attitude Scale (MAS) and identified four dimensions of money attitude. The first dimension is power-prestige, in which money is the symbol of success and power in the individuals' attitudes the second dimension is retention-time. In the case of individuals in this group, the main focus is on preparation for the future and keeping the financial situation under continuous control. For them, saving and amassing are of primary importance, and they regularly record the situation of their finances. The third dimension is distrust. The common feature of individuals in this category is that they look at money with suspicion, almost with fear. Individuals that have no trust in money and finances, usually do not trust themselves enough either. The fourth and last dimension of the authors is anxiety, and includes individuals prone to worrying and distress over money matters. Chan (2003) compares financial approaches with the consumer types described by Sproles and Kendall (1986) applying Yamauchi and Templer's (1982) theory. People who regard money as a symbol of power are mainly quality-oriented and novelty seeking consumers. People who have a distrustful attitude to money tend to be uncertain about and frustrated with their consumer decisions. Consumers with an anxious attitude usually suffer from ambivalent feelings in their consumer decision-making as they are seeking both pleasure and price-quality balance concurrently.

Furnham (1984) developed a standard measure of money-related beliefs and behaviour patterns called the Money Beliefs and Behaviours Scale (MBBS). The 60-item scale is further reduced to six factors, namely: obsession, power/spending, retention, security/conservative, inadequacy, and effort/stability. In an investigation among teenagers, Furnham (1999) defined money attitudes as attitudes to spending and saving, and with respect to the age characteristics of the target group, applied a scale different from the MBBS scale (Furnham, 1984). In the end, the 20-statement-scale resulted in five factors, labelled as spending money, saving money, mechanics of banking, work ethic and indifference to money. Wilhelm Stern was the first psychologist to study personality. Since Stern, the recognition of "self" has been considered as the essential condition of a personality. This is the ability of the individual to distinguish themselves from their environment. Only humans possess a personality. According to Stern, personality is a manifold, dynamic unit. Personality psychology is a branch of psychology that studies how internal and external factors affect the development of personality. Personality is the ensemble of traits that distinguish an individual from other people and that an individual has by nature and gains later in their life. Several studies have shown the existence of a strong relationship between personality and making wrong financial decisions (see e.g. Jureviciene and Jermakova, 2012, Iqbal et al., 2012; Brozynski et al., 2004). The most common model of trait research is the five-factor personality model (McCrae, 2009). The five factors, referred to as the "Big Five" since Goldberg (1971), are Openness to Experience, Conscientiousness, Extraversion, Agreeableness and Neuroticism or Emotional Stability (Borghans et al., 2008). According to the results by Kübilay and Bayrakdaroğlu (2016), each personality type faces different biases and each investor has different risk tolerance.

Mellan (1994) identifies nine personality types on the basis of their attitude to money: hoarder, spender, money monk, money avoider, money amasser, binger, money worrier, risk-taker, and risk-avoider. A hoarder is an individual who sticks to their money, finds it hard to buy things that would cause momentary pleasure to themselves or their beloved ones. Money represents a certain security to them, thereby being estranged from all kinds of hedonistic behaviour. Spenders find pleasure in spending their money when and on what they feel necessary - this status is usually related to an external stimulus. Saving money and making budgets 
are not characteristic features of this personality type. Money monks feel bad when in possession of a lot of money. Such situations bring about a certain sense of guilt in them, especially when they come into a large sum of money. They are convinced that money spoils everything. Money avoiders try to avoid daily tasks about money. Individuals belonging to this group do not like to deal with their finances, so they usually also do not produce budgets. Money amassers consider the amount of money available to them - or rather the increase of it - one of their main objectives, as they consider that ultimately this is the way they can also prove their power. Mellan (1994) refers to a combination of the hoarder and spender personality types as a binger. Bingers tend to economize for a while (e.g. for the achievement of a major objective), but if affected by an external stimulus (impulse), they are susceptible to shop without consideration. The common characteristic feature of money worriers is that they lack self-confidence, they are afraid to lose control and therefore they keep control over their finances. They tend to continuously monitor their financial situation. Risk-takers perceive money as a source of means adventure, excitement and freedom. They enjoy risking their money as they enjoy the shivering and adrenaline that come with it. Mellan's (1994) last category is the group of risk-avoiders. For them, money equals security; therefore, they prefer keeping their money at home, if they can. Table 1 provides a summary of the results of the studies presented beforehand.

Table 1: A summary on research on financial attitude and financial personality types

\begin{tabular}{ll}
\hline Author(s) & Dimensions of financial personality and attitude \\
\hline Goldberg and Lewis (1978) & miser \\
Forman (1987) & autonomy worshipper \\
& power grabber \\
& gambler \\
Yamauchi and Templer (1982) & power-prestige \\
& retention-time \\
& distrust \\
& anxiety \\
& obsession \\
Furnham (1984) & power \\
& retention \\
& security \\
& inadequacy \\
& effort/ability \\
& budget \\
negative feelings about money & money as a token of success \\
Tang (1992) & hoarder \\
spender \\
Mellan (1994) & money monk avoider \\
& money amasser \\
& binger \\
money worrier \\
risk-taker \\
risk-avoider \\
\end{tabular}

Based on the above, one can state that a considerable amount of research has been devoted to financial personalities, but, at the same time, one can equally note that certain personality types cannot be clearly distinguished from each other: there are some overlaps between them. It is important to note that all dimensions of financial personality or financial behaviour do not always appear in each related study. The dimensions of retention and time, as well as negative feelings about money are recurring elements of these studies. The widest profile range was offered by the works of Furnham (1984) and Mellan (1994). Similar personality types were found in the empirical part of the present research. 


\section{Methodology}

To identify financial personalities, the authors of the present study used a personality test containing 36 statements (Németh et al., 2016; Béres et al., 2015). To test their financial personality and to study what behavioural patterns, habits and attitudes characterize them; respondents who visited the site http://penziranytu.hu/penzugyi-szemelyisegteszt were asked to complete an online questionnaire. Respondents had to decide the extent to which they were characterized by each statement of the questionnaire using a five-point Likert-scale where 1 indicated "strongly disagree", and 5 indicated "strongly agree". During the summer of 2015, 3,139 respondents filled in the questionnaire and following data cleaning the sample consisted of a total of 3,088 responses. The low dropout rate is the result of a number of preliminary methodological considerations. First, respondents typically did not interrupt the process of questionnaire response. Interruption usually happens when respondents fail to understand the statements and/or questions, or if they consider the questionnaire boring or too intrusive. Second, very few straight-line or pattern responses (i.e. responding without thought by answering the same for all statements or by recording a pattern [e.g. zigzag or Christmas-tree]) were recorded. None of the above issues occurred, thanks to the following considerations: 1. Phrasing: Statements were phrased in a way that ordinary people could understand them, without perceiving them as too scientific or the topic as remote. This allowed for minimizing the risk of misunderstanding. 2. Sensitive issues: Sensitive issues were completely omitted from the present questionnaire, i.e. beyond the test containing the 36 statements, respondents were not asked for any additional socio-demographic data (e.g. to state their income). The lack of these former can also be interpreted as a limitation of the research, however, the resulting increase in confidence allowed for a considerable increase in the willingness to reply. 3. Motivation: Following the completion of the personality test, respondents were immediately provided with the evaluation of their profile. The inclusion of feedback equally facilitated the willingness to participate.

The main aim of the financial culture research conducted by market research company GfK and the Financial Compass Foundation (Pénziránytű Alapítvány) was to assess the financial awareness and literacy of Hungarian adults. The OECD produced a unified international methodology that was joined by Hungary along 13 other countries - in 2010. The Financial Compass Foundation once again participated in the study in 2015, with, this time, about 30 countries conducting the research at the same time. The methodology based on a standard questionnaire allows for comparable results among countries as well as for an examination of time series data. Data was collected with CAPI (Computer-Aided Personal Interviewing). As numerous demographic data were queried, one can state that respondents' age varied between 18 and 79 years. 1000 individuals were surveyed, representing the population of Hungary by age, gender and type of settlement. The advantage of personal interviews is that respondents are likely to complete the survey and without the possibility of "running through" the questionnaire (even without reading it) as the interviewer is in control of the pace by reading out loud the questions and statements of the questionnaire. Its disadvantage, however, is that respondents may be prone to provide answers that they assume are expected of them, thereby trying to meet social expectations, potentially reducing the proportion of honest answers (Malhotra \& Simon, 2009; Atkinson \& Messy, 2012).

Financial attitudes, time orientation, and money-related emotions are measured through a 12-item part of the questionnaire. Respondents had to decide the extent to which they agreed with each statement using a fivepoint Likert-scale where 1 indicated "strongly agree", and 5 indicated "strongly disagree". This direction of this scaling is the opposite of the one used for the financial personality test presented beforehand. Thus, in order to facilitate the analysis and provide comparability, responses gathered through the OECD questionnaire were reverse-coded in order for higher scores to represent higher respondent agreement. As these statements overlap with certain statements of the 36-item personality test in some respect, the present study examines and then compares the results of the two queries. The 12 relevant items of the OECD questionnaire were grouped into three factors as a result of a factor analysis (main component analysis with varimax rotation). K-means clustering was then used based on factor averages and resulted in the identification of 3 respondent segments. K-means clustering was chosen for its stability for a large sample size (Sajtos \& Mitev, 2007). 


\section{Results}

Results of the financial personality survey: Descriptive statistics of the 36-item scale developed by Erzsébet Németh are first examined. Table 2 gives an overview of the mean and standard deviation values for the 36 statements in an ascending order based on means. The lowest mean value (1.51) was obtained for the statement "I often have to borrow at the end the month", while the highest (4.27) for "I know exactly how much money I have in cash and on my bank account". This latter equally has the lowest standard deviation value (1.031), suggesting a convergence of respondents' answers in this regard. The highest standard deviation value (1.465) was observed for the "Bills are killing me" item. Approximately 45 percent of respondents indicated that economizing was totally true for them when they had little money, and also, that they did not like to throw out still usable things, which we also evaluated in a positive way, as the former reflects an economizing character, while the latter reflects the proper assessment of values. In addition, more than 30 percent of respondents thought it was completely true for them that they controlled their spending, always had enough savings, compared the prices in shops where they took shopping lists compiled with proper consideration.

Table 2: Questionnaire item scores (1 - strongly disagree, 5 - strongly agree)

\begin{tabular}{lll}
\hline Descriptive statistics & Mean & St.dev. \\
\hline I often have to borrow at the end the month. & 1.51 & 1.056 \\
I enjoy going shopping with friends. & 1.70 & 1.060 \\
I am in a desperate fix with debts. & 1.82 & 1.284 \\
I am puzzled about where your money goes. & 1.94 & 1.218 \\
If I pay in cash I never ask for the change. & 1.95 & 1.114 \\
Only when I clean up I realize the amount of my unnecessary purchases. & 1.99 & 1.100 \\
I sometimes end up paying a few bills late. & 2.03 & 1.368 \\
I enjoy trying my luck. & 2.08 & 1.141 \\
I often surprise my loved ones with self-made gifts. & 2.15 & 1.151 \\
I don't enjoy cooking, we rather eat ready meals. & 2.16 & 1.268 \\
Bills are killing me. & 2.43 & 1.465 \\
If I like something, I buy it. & 2.53 & 1.109 \\
When grocery shopping, I am often surprised how much I have to pay at & 2.56 & 1.202 \\
the end. & & \\
I love trendy things. & 2.58 & 1.250 \\
I have a hard time resisting when I am offered something at a great & 2.67 & 1.216 \\
price. & & \\
I have a few bad habits that cost me a lot of money. & 2.69 & 1.279 \\
I often reward myself. & 2.69 & 1.083 \\
I enjoy going out with my friends. & 2.79 & 1.333 \\
I spend a lot on healthy food and mineral water. & 2.81 & 1.178 \\
Sometimes, when shopping, I spend more than I previously expected. & 3.03 & 1.114 \\
I like it when it's warm at the apartment. & 3.10 & 1.156 \\
When I need more money, I take up extra work. & 3.13 & 1.417 \\
I prefer preparing sandwiches rather than shopping at the cafeteria. & 3.20 & 1.411 \\
I always have enough savings for unexpected expenses. & 3.39 & 1.461 \\
I know exactly the price of everything. & 3.44 & 1.140 \\
I tend to browse a lot before purchasing a product. & 3.52 & 1.243 \\
I want to provide everything for my children. & 3.60 & 1.271 \\
\hline & & \\
& & \\
& &
\end{tabular}




\begin{tabular}{lll}
\hline I keep my household in order. & 3.61 & 1.102 \\
I am good at rationing my money. & 3.61 & 1.131 \\
I keep good track of my expenses. & 3.64 & 1.263 \\
I always make a shopping list. & 3.65 & 1.360 \\
Before going shopping, I always carefully think through of what I need. & 3.83 & 1.088 \\
I always compare prices before purchasing anything. & 3.93 & 1.096 \\
I only save on my expenses when I am short of money. & 3.98 & 1.176 \\
I don't like throwing out things that still can be used. & 4.08 & 1.066 \\
I know exactly how much money I have in cash and on my bank account. & 4.27 & 1.031 \\
\hline
\end{tabular}

A questionnaire item can be considered divisive when all possible answers $(1,2,3,4$, or 5$)$ are provided by at least $14 \%$ of respondents each. Among the 36 statements the three following turned out to be most divisive:

- When I need more money, I take up extra work.

- I prefer preparing sandwiches rather than shopping at the cafeteria.

- I always have enough savings for unexpected expenses.

Financial personality types: The factor analysis (main component analysis with varimax rotation) conducted on the 36 statements yielded 9 factors, namely:

- Economizer with little money

- Money-devourer (opposite of Moderate)

- Order creates value

- Price sensitive

- Collector

- Planner

- Ups and downs

- Diligent

- Cannot control finances

The dimension of economizer with little money includes people who have trouble managing their finances, most of them struggle with debts, but at the same time and as opposed to it, it may happen that they also have some savings. Among the characteristic features of money-devourers, it is primarily the short-term features that dominate - they love to have fun, they immediately buy what they like, they love shopping and often reward themselves. Moreover risk-taking is also present among them. Respondents performing well in the order creates value factor keeps track of his expenses, knows exactly when and how much money he has, and from this, it partly comes that he keeps his home and household tidy, and before shopping, always thinks over what he needs. The price-sensitive dimension contains people for whom it is most typical that they compare prices before shopping, and as a result, are able to take their time in selecting the articles. Collectors take advantage of sales and try to amass everything. They do not necessarily keep their environment tidy, but when they do, they realize how many unnecessary things they have. Planners make lists before going shopping, i.e. they tend to carefully plan their purchases. In the ups and downs dimension, savers and spenders appear alongside each other. The central organizing principle of the diligent dimension is work, in connection with which individuals assess the acquired income, and as a consequence, they are able to appreciate it. Individuals who cannot control finances are not able to appreciate the real value of the goods they wish to consume, and over the short term it means that they are surprised at the amount they have to pay at the cashdesk.

Results of the OECD financial literacy study: The 12 items of the OECD pertaining to personal finances were first examined in terms of the resulting mean values (Table 3). 
Table 3: Questionnaire item scores (1 - strongly disagree, 5 - strongly agree)

\begin{tabular}{lll}
\hline Descriptive statistics & Mean & St.dev. \\
\hline I am willing to risk some of my money when it comes to savings or investment & 1.6653 & 1.01695 \\
I currently have too many debts & 1.9186 & 1.26650 \\
I enjoy spending money more than saving it for later & 2.1903 & 1.18502 \\
I rather live a day at a time - I'll manage tomorrow somehow & 2.2432 & 1.20116 \\
I am satisfied with my current financial situation & 2.4050 & 1.23633 \\
I am often worried about my ordinary living expenses & 3.0700 & 1.36050 \\
Money is meant to be spent & 3.1240 & 1.19501 \\
I set up long-term financial goals and strive to achieve them & 3.2265 & 1.31301 \\
I am restricted by my financial situation in doing things I consider important & 3.5180 & 1.29080 \\
I personally and carefully monitor my finances & 3.5681 & 1.31912 \\
Before purchasing something I carefully consider whether I can afford it & 4.1782 & .99108 \\
I pay my bills in time & 4.2863 & 1.01776 \\
\hline
\end{tabular}

A factor analysis (main component analysis with varimax rotation) was conducted for the 12 items. The analysis yielded the three factors presented in Table 4. The worries and dissatisfaction with regards to finances appear in the first factor, which thus regrouping variables in connection with negative feelings about finances. It is important to note that the item related to satisfaction loads negatively in the factor structure, hence indicating dissatisfaction. The second factor gathers statements that represent a certain presenthedonistic (Zimbardo \& Boyd, 1999) attitude. A "carpe diem" attitude characterizes this factor, with recklessness, a certain negligence towards obligations (e.g. paying bills), and spending prevailing over building up reserves. The third factor includes items on consciousness, i.e. having goals and monitoring finances. The willingness to take risks equally appears here, only in connection with savings and investment. The three factors are suitable for a K-means cluster analysis to be performed on the averages on the related scale item scores in order to divide respondents into groups.

Table 4: The three factors and item factor scores as identified by the factor analysis

\section{Results of the factor analysis}

\begin{tabular}{llll} 
& \multicolumn{2}{l}{ Component } \\
& $\mathbf{1}$ & $\mathbf{2}$ & $\mathbf{3}$ \\
\hline I am often worried about my ordinary living expenses & .840 & -.005 & -.086 \\
I am restricted by my financial situation in doing things I consider important & .810 & .022 & -.155 \\
I am satisfied with my current financial situation (R) & .765 & -.162 & -.205 \\
I currently have too many debts & .592 & .309 & .336 \\
I enjoy spending money more than saving it for later & -.033 & .774 & -.062 \\
I rather live a day at a time - I'll manage tomorrow somehow & .027 & .725 & -.168 \\
Money is meant to be spent & .100 & .567 & -.112 \\
Before purchasing something I carefully consider whether I can afford it (R) & -.379 & .532 & .026 \\
I pay my bills in time etc. (R) & .462 & .520 & .060 \\
I set up long-term financial goals and strive to achieve them & -.154 & -.271 & .739 \\
I personally and carefully monitor my finances & .004 & -.304 & .635 \\
I am willing to risk some of my money when it comes to savings or investment & -.138 & .410 & .597
\end{tabular}

$R:$ reverse-coded 
Cluster analysis: The clusters obtained by the K-means cluster analysis provide a deeper insight and a more detailed picture of the results by the help of the combination of factors. The cluster analysis was performed using the averages of the item scores of each factor. Sizes and centres of the three resulting clusters are shown in Table 5.

Table 5: Cluster centres in the three clusters based on factors

\begin{tabular}{llll}
\hline Final cluster centres & $\begin{array}{l}\text { Cluster } \\
\text { ( } \mathbf{N = 3 0 5 )}\end{array}$ & $\mathbf{2}(\mathbf{N}=\mathbf{3 5 9})$ & $\mathbf{3}(\mathbf{N}=\mathbf{3 0 0})$ \\
\hline Carpe Diem factor & 8.74 & 9.47 & 15.17 \\
Self-conscious factor & 8.06 & 9.26 & 8.05 \\
Worried, dissatisfied factor & 15.52 & 8.21 & 13.28 \\
\hline
\end{tabular}

The first cluster is least likely to reach a high score at the "carpe diem" factor, while at the same time they are most prone to providing high scores for the items of the worried-dissatisfied factor. As a consequence, this group of respondents can be characterized as being anxious about their finances, who dare not live for the day or spend money irresponsibly. This, however, does not entail a higher level of consciousness. The second cluster performs highest in consciousness, while in terms of negative feelings, they are the least anxious or dissatisfied about their finances. Compared to the other clusters, the third cluster performs remarkably high in the "carpe diem" factor. These respondents are thus most likely to live a day at a time, but also to worry about their finances, even though not as much as those respondents who belong in the first cluster. Next, the average scores in each factor of the focal 12 items were examined. Table 7 contains the item scores within the full sample and within each factor. Based on the mean values, Table 6 gives an overview of the main attributes of each cluster.

Table 6: Description of clusters

\begin{tabular}{|c|c|c|}
\hline $\begin{array}{l}\text { Cluster } 1 \\
\text { Anxious unsatisfied }\end{array}$ & $\begin{array}{l}\text { Cluster } 2 \\
\text { Satisfied conscious }\end{array}$ & $\begin{array}{l}\text { Cluster } 3 \\
\text { Moderately } \\
\text { unconsidered }\end{array}$ \\
\hline $\begin{array}{l}\text { careful in their spending } \\
\text { least likely to live a day at a time } \\
\text { do not prefer spending over } \\
\text { savings } \\
\text { lowest risk-taking willingness } \\
\text { most unsatisfied } \\
\text { most anxious } \\
\text { most perceiving their financial } \\
\text { situation as prohibitive }\end{array}$ & $\begin{array}{l}\text { most likely to pay their } \\
\text { obligations in time } \\
\text { most likely to set up financial } \\
\text { goals and control their } \\
\text { finances } \\
\text { least anxious } \\
\text { least likely to have debt and to } \\
\text { perceive their financial } \\
\text { situation as prohibitive } \\
\text { most satisfied }\end{array}$ & $\begin{array}{l}\text { live a day at a time } \\
\text { least likely to formulate and } \\
\text { set up financial goals } \\
\text { least likely to monitor and } \\
\text { control their finances } \\
\text { prefer spending over savings } \\
\text { least likely to pay their } \\
\text { obligations (e.g. bills) in time } \\
\text { highest risk-taking willingness } \\
\text { feel crushed by their debts }\end{array}$ \\
\hline
\end{tabular}

Table 7: Item scores within the full sample and within factors Descriptives

\begin{tabular}{lllll} 
& & N & Mean & Std. Dev. \\
\hline Before purchasing something I carefully & 1 & 305 & 4.7574 & .59062 \\
consider whether I can afford it & 2 & 359 & 4.1253 & .93856 \\
& 3 & 300 & 3.6567 & 1.05633 \\
& Total & 964 & 4.1795 & .98796 \\
I rather live a day at a time - I'll manage & 1 & 305 & 1.6590 & .92931 \\
tomorrow somehow & 2 & 359 & 1.8301 & .92549 \\
& 3 & 300 & 3.2567 & 1.01697 \\
\hline
\end{tabular}




\begin{tabular}{|c|c|c|c|c|}
\hline \multicolumn{5}{|c|}{$\begin{array}{l}\text { Journal of Economics and Behavioral Studies (ISSN: 2220-6140) } \\
\text { Vol. 9, No. 2, pp. 46-57, April } 2017 \\
\end{array}$} \\
\hline \multirow{4}{*}{$\begin{array}{l}\text { I enjoy spending money more than saving } \\
\text { it for later }\end{array}$} & Total & 964 & 2.2199 & 1.18461 \\
\hline & 1 & 305 & 1.5213 & .76113 \\
\hline & 2 & 359 & 1.8357 & .92347 \\
\hline & 3 & 300 & 3.2467 & 1.05334 \\
\hline \multirow{4}{*}{ I pay my bills in time, etc. } & Total & 964 & 2.1753 & 1.17493 \\
\hline & 1 & 305 & 4.3902 & .92582 \\
\hline & 2 & 359 & 4.8106 & .45193 \\
\hline & 3 & 300 & 3.6033 & 1.14178 \\
\hline \multirow{4}{*}{$\begin{array}{l}\text { I am willing to risk some of my money } \\
\text { when it comes to savings or investment }\end{array}$} & Total & 964 & 4.3019 & 1.00112 \\
\hline & 1 & 305 & 1.3246 & .74088 \\
\hline & 2 & 359 & 1.6880 & 1.02899 \\
\hline & 3 & 300 & 2.0033 & 1.14061 \\
\hline \multirow{4}{*}{$\begin{array}{l}\text { I personally and carefully monitor my } \\
\text { finances }\end{array}$} & Total & 964 & 1.6712 & 1.02145 \\
\hline & 1 & 305 & 3.6328 & 1.39651 \\
\hline & 2 & 359 & 3.8942 & 1.10860 \\
\hline & 3 & 300 & 3.1867 & 1.29773 \\
\hline \multirow{4}{*}{$\begin{array}{l}\text { I set up long-term financial goals and } \\
\text { strive to achieve them }\end{array}$} & Total & 964 & 3.5913 & 1.29660 \\
\hline & 1 & 305 & 3.0984 & 1.34635 \\
\hline & 2 & 359 & 3.6769 & 1.19182 \\
\hline & 3 & 300 & 2.8600 & 1.22695 \\
\hline \multirow{4}{*}{ Money is meant to be spent } & Total & 964 & 3.2396 & 1.30007 \\
\hline & 1 & 305 & 2.7115 & 1.24949 \\
\hline & 2 & 359 & 2.7409 & 1.03420 \\
\hline & 3 & 300 & 3.9233 & .86407 \\
\hline \multirow{4}{*}{$\begin{array}{l}\text { I am restricted by my financial situation in } \\
\text { doing things I consider important }\end{array}$} & Total & 964 & 3.0996 & 1.19554 \\
\hline & 1 & 305 & 4.4492 & .81002 \\
\hline & 2 & 359 & 2.3760 & 1.00312 \\
\hline & 3 & 300 & 3.8867 & .95754 \\
\hline \multirow{4}{*}{$\begin{array}{l}\text { I am often worried about my ordinary } \\
\text { living expenses }\end{array}$} & Total & 964 & 3.5021 & 1.29180 \\
\hline & 1 & 305 & 4.1279 & .99673 \\
\hline & 2 & 359 & 1.9694 & .91947 \\
\hline & 3 & 300 & 3.3367 & 1.13178 \\
\hline \multirow{3}{*}{ I currently have too many debts } & Total & 964 & 3.0778 & 1.36153 \\
\hline & 1 & 305 & 2.3574 & 1.44646 \\
\hline & 2 & 359 & 1.2006 & .54301 \\
\hline \multirow{6}{*}{$\begin{array}{l}\text { I am satisfied with my current financial } \\
\text { situation }\end{array}$} & 3 & 300 & 2.3733 & 1.31137 \\
\hline & Total & 964 & 1.9315 & 1.27337 \\
\hline & 1 & 305 & 1.4164 & .71662 \\
\hline & 2 & 359 & 3.3398 & .87571 \\
\hline & 3 & 300 & 2.3133 & 1.17747 \\
\hline & Total & 964 & 2.4118 & 1.23109 \\
\hline
\end{tabular}


Comparison of the results: The first factor based on the items of the OECD questionnaire (anxious unsatisfied) echoes with the economizer with little money factor yielded by the study on financial personalities. This is the dimension of money avoiders that points out that respondents performing highly here are likely to have problems related to the handling of their finances and also to struggle with debt. The second factor, "carpe diem" shows similarities with the money-devouring factor. Results of the research on financial personalities suggest a certain short-sightedness, as well as shopping and self-rewarding as core values for this factor. Thus, here, spending money dominates over saving it. The third factor regrouping the dimensions of objectives and control shows resemblance to the order creates value factor. This is a dimension with positive views and pertains to respondent's level of prudence by revealing how they keep track of their finances. The similarities between the two factor analyses are illustrated in Figure 1.

Figure 1: Relationships between the factors of the two studies

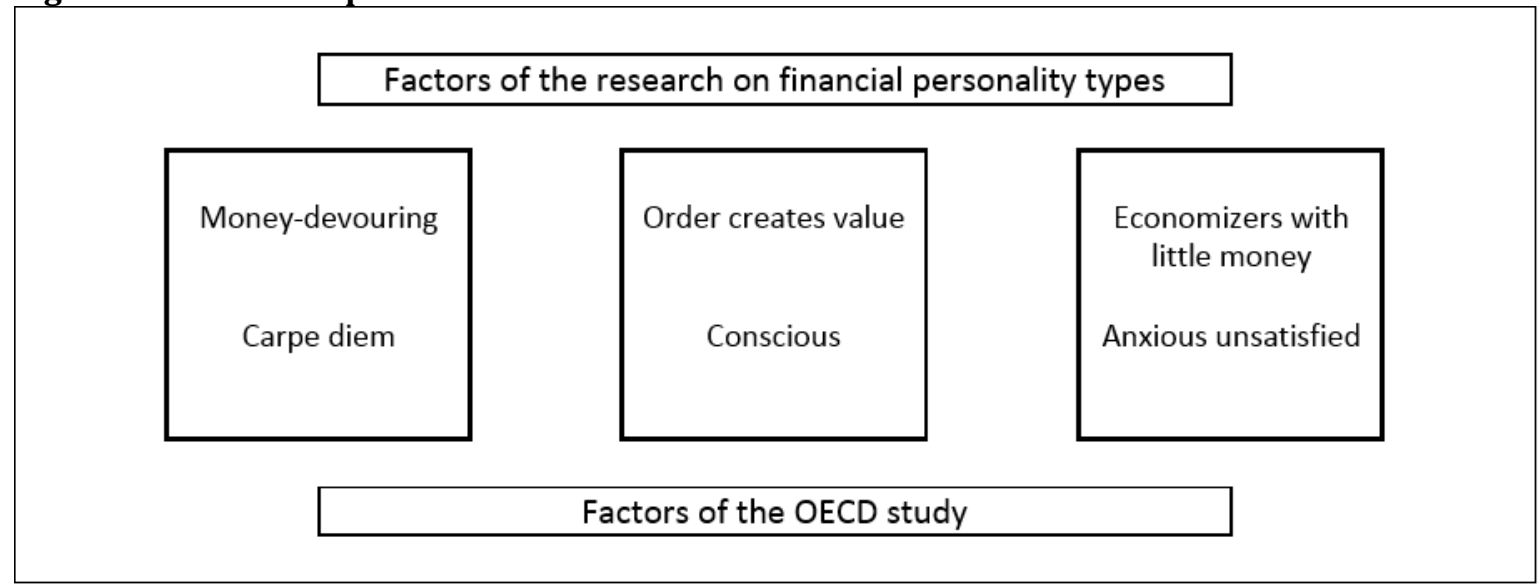

(source: own elaboration)

The three clusters identified based on the OECD database cover - both in contents and in their characteristics - all nine identified financial personality types. The first cluster, anxious unsatisfied, regroups the economizers with little money, price sensitive, and collector personality types. The second cluster, satisfied conscious, includes the order creates value, diligent and planner personalities. The third cluster, moderately anxious unconsidered, covers the money-devouring, ups and downs and cannot control finances personalities.

Figure 2: Financial personality types covered by the clusters of the OECD study

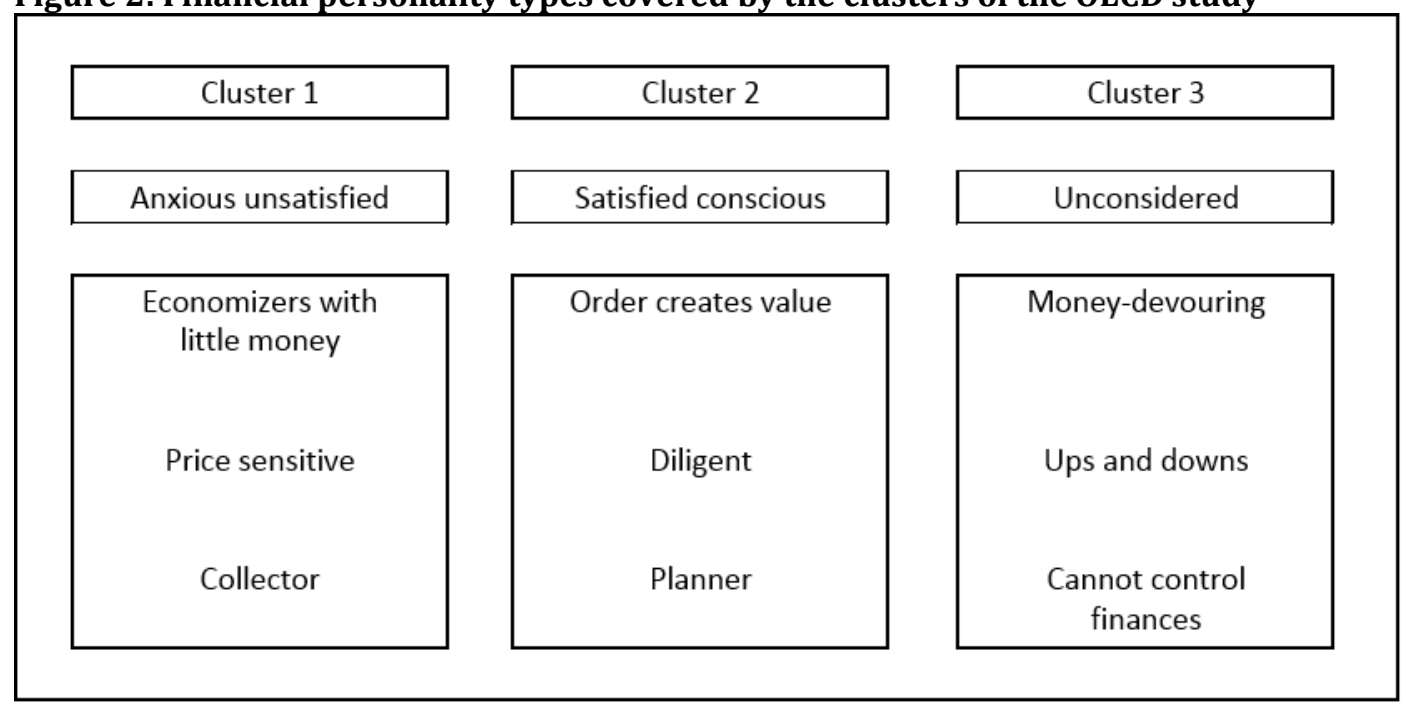

(source: own elaboration) 


\section{Conclusion}

Modern economics have recognized that in order to effectively forecast financial and economic processes it is primordial to understand the attitudes of the members of society toward finances, as well as the characteristics of various social group sharing the same views and behaviours. The aim of the present study was to compare the relevant parts of two studies conducted in 2015 focusing on financial attitudes and behaviour, and therefore on financial personality types. The theoretical framework reviews various scales developed since as early as the 1970s. Both the study of financial personality types and the OECD study verify and overlap, to varying degrees, with the results of this framework. The nine financial personality profiles can be matched with the three clusters identified in the OECD study. The clusters identified during the research show idiosyncratic financial and psychological vulnerability and/or protection. The main conclusion is that self-consciousness in finances is associated with an emphasis on order, planning and diligence. Individuals in the group that does so are also most satisfied with their current financial situation. A combination of these attributes can, therefore, provide a protection of sorts both financially and mentally.

The literature review hints that concern and negative feelings are recurring dimensions of individual finances. The group of anxious identified during the cluster analysis covers individuals who are characterized by usually having little money, price sensitivity and a collecting behaviour. Moreover, they consider that they economize well; still they are dissatisfied with their financial situation. The source of their dissatisfaction can be traced to low income and to the feeling of vanity in trying to make do with their finances. Here, amassing and anxiety are a cause of financial and mental vulnerability, respectively. Individuals in the third group, unconsidered, cannot control their finances and have a lot of purposeless expenditures. This group is in fact the opposite of Yamauchi and Templer's (1982) retention-time dimension. In the financial personality study the "order creates value" factor was identified to be the best indicator of one's financial awareness. This analogy, emphasized in the study, equally supports our earlier finding, as this factor is precisely most in line with the self-conscious factor.

The second cluster, satisfied conscious, includes the order creates value, diligent and planner personalities. These dimensions were most highly regarded in the study in terms of financial personality. This is also the group with the highest levels of income. An interesting avenue for further research is the study of whether high levels of income necessarily lead to higher financial awareness and satisfaction, or, on the contrary, is it a positive and conscious attitude that leads to higher levels of income. Identifying the personality, attitude, and behavioural components of financial culture can help contribute to a better understanding of the causes and aspects of financial behaviours beyond rationality. The present study provides a synthesis of two studies performed in Hungary as well as of relevant parts of the literature. It contributes to the research on the broader concept of financial literacy and thereby can serve as an input for further studies as well as for the development of programs on improving financial literacy.

\section{References}

Atkinson, A. \& Messy, F. A. (2012). Measuring Financial Literacy: Results of the OECD / International Network on Financial Education (INFE) Pilot Study, OECD Working Papers on Finance, Insurance and Private Pensions, No. 15, OECD Publishing, Paris.

Béres, D., Huzdik, K., Németh, E. \& Zsótér, B. (2015.) Pénzügyi személyiség. A magyar lakosság pénzügyi magatartása, szokásai és attitűdjei [Financial personality. Financial behaviour, habits and attitudes of the Hungarian population]. Research report. Financial Compass Foundation (Pénziránytü Alapítvány), Budapest.

Borghans, L., Angela, L. D., James, J. H. \& Baster, W. (2008). The Economics and Psychology of Personality Traits, Discussion Paper No: 3333. Forschungsinstitut zur Zukunft der Arbeit Institute for the Study of Labor.

Botos, K., Botos, J., Béres, D., Csernák, J. \& Németh, E. (2012). Financial literacy and Risk-Taking of Households in the Hungarian Central Great Plain. Public Finance Quarterly, 57(3), 267-285

Brozynski, T., Lukas, M. \& Ulrich, S. (2004). The Impact of Experience on Risk Taking, Overconfidence and Herding of Fund Managers: Complementary Survey Evidence. Discussion Paper No: 292. University of Hannover School of Economics and Management. 
Chan, S. Y. F. (2003). The exploratory relationship between money attitude and consumer style. Australian Journal of Psychology, 55, 119-119.

Forman, N. (1987). Mind over money. Toronto: Doubleday.

Furnham, A. F. (1984). Many sides of the coin: The psychology of money usage. Personality and Individual Differences, 5(5), 501-509.

Furnham, A. (1999). The saving and spending habits of young people. Journal of Economic Psychology, 20 (6), 677-697.

Goldberg, L. R. (1971). A Historical Survey of Personality Scales and Inventories. In Paul McReynolds (Ed.), Advances in Psychological Assessment, 2, 293-336. USA: Science and Behavior Books Inc.

Goldberg, H. \& Lewis, R. T. (1978). Money Madness: The Psychology of Saving, Spending, Loving and Hating Money. William Morrow and Co., New York.

Huzdik, K., Béres, D. \& Németh, E. (2014). An Empirical Study of Financial Literacy versus Risk Tolerance Among Higher Education Students. Public Finance Quarterly, 59(4), 476-488.

Iqbal, S. M. J., Muneer, S., Jahanzeb, A. \& Rehman, S. U. (2012). A Critical Review of Capital Structure Theories. Information Management and Business Review, 4(11), 553-557

Jureviciene, D. \& Jermakova, K. (2012). The Impact of Individuals' Financial Behaviour on Investment Decisions. Annual meeting fort he Society of 1 st. Electronic International Interdisciplinary Conference, Slovakia, September 3-7.

Kübilay, B. \& Bayrakdaroğlu, A. (2016). An Empirical Research on Investor Biases in Financial DecisionMaking, Financial Risk Tolerance and Financial Personality. International Journal of Financial Research, 7(2), 171-182.

Malhotra, N. K. \& Simon, J. (2009). Marketingkutatás [Marketing research]. Akadémiai Kiadó Zrt., Budapest.

Mellan, 0. (1994). Money Harmony: Resolving Money Conflicts In Your Life and Relationships. Walker \& Company, New York

Magyar Nemzeti Bank [the Central Bank of Hungary]. (2014). Tudás és érték, a Magyar Nemzeti Bank társadalmi felelősségvállalási stratégiája [Knowledge and values, corporate social responsibility strategy of the central bank of Hungary]. Magyar Nemzeti Bank, June 2014, https://www.mnb.hu/letoltes/mnb-csr-kiadvany-eng-final-1.pdf

McCrae, R. R. (2009). The Five-Factor Model of Personality Traits: Consensus and Controversy. In Philip J. Corr and Gerald Matthews (Eds.), The Cambridge Handbook of Personality Psychology (pp. 148-162). Cambridge: Cambridge University Press.

Németh, E., Béres, D., Huzdik, K. \& Zsótér, B. (2016). Financial personality types in Hungary - research methods and results. Financial and Economic Review, 15(2), 153-172.

Opsahl, R. L. \& Dunnette, M. D. (1966). The role of financial incentives in industrial motivation. Psychological Bulletin, 66, 95-116.

Sajtos, L. \& Mitev, A. (2007). SPSS kutatási és adatelemzési kézikönyv [SPSS Research and Data Analysis Manual]. AlineaKiadó, Budapest.

Sproles, G. B. \& Kendall, E. L. (1986). A methodology for profiling consumers' decision-making styles. Journal of Consumer Affairs, 20(2), 267-279.

Tang, T. L. P. (1992). The Meaning of Money Revisited. Journal of Organizational Behaviour, 13(2), 197-202.

Wernimont, P. F. \& Fitzpatrick, S. (1972). The meaning of money. Journal of Applied Psychology, 56 (3), 218226.

Yamauchi, K. T. \& Templer, D. J. (1982).The Development of a Money Attitude Scale. Journal of Personality Assessment, 46(5), 522-528.

Zimbardo, P. G. \& Boyd, J. N. (1999). Putting Time in Perspective: A Valid, Reliable Individual-Differences Metric. Journal of Personality and Social Psychology, 77(6), 1271-88.

Zsótér, B., Németh, E. \& Béres D. (2016). A pénzügyi kultúra személyiség-, attitűd- és viselkedésbeli komponensei - Összehasonlító elemzés. [Components of financial literacy from the perspective of personality, attitudes and behaviour. Comparative study]. Kultúra és Közösség / Culture and Community, 41(3)89-102. 